\title{
Chromatographic Determination of Azoxystrobin, Fenhexamid and Lufenur on Residues in Grapevine
}

\author{
Manal R. Montasser ${ }^{1}$ and Hend A. Mahmoud ${ }^{2}$
}

\begin{abstract}
Residues of azoxystrobin (Amistar 25\% SC), fenhexamid (Telidor 50\% SC) and lufenuron (Match 5\% EC) were determined on grapes treated with recommended doses. Grape leaves and fruit samples randomly collected after $1 \mathrm{hr}, 1,3,6,10,15$ and 21 days of application, were extracted, cleaned-up and analyzed using chromatographic methods. Azoxystrobin, fenhexamid and lufenuron residues were dissipated on grape leaves after ten days of treatment by $87.83,99.23$ and $99.29 \%$ of the initial concentration, respectively. The corresponding values for dissipation of mentioned pesticides on grape fruits were $93.55,99.62$ and $99.99 \%$ of the initial concentration, respectively. The pre-harvest intervals (PHI) were calculated to be 6,10 and 7 days after application of azoxystrobin, fenhexamid and lufenuron on grapes, respectively.
\end{abstract}

\section{INTRODUCTION}

Grape Vitis vinifera is the most widely cultivated fruit crop all over the world, covering an area of more than 10 million hectares, as it is grown within the temperate to the tropical regions (Mansour, 2005). In Egypt grape is a widely cultivated fruit crop, it is considered to be the second most important fruit crop after citrus. In Egypt, grapes are consumed as leaves and fruits. The total cultivated area in Egypt with grapes increased from 130,581 feddans in 1995 to 160,005 feddans in 2005. Its production also increased from 914,485 tonnes to $1,391,749$ tonnes. The quantity exported in the year 2006 reached to 68,296 tonnes (HRI, 2008).

Grapevines are normally subjected to fungi (such as grey rot, Botrytis cinerea; downy mildew, Plasmopora viticola and black mould Aspergillus niger) or insects attacks (such as grape fruit worm Eudemis botrana). Fungicides (azoxystrobin and fenhexamid) and insecticide (lufenuron) are applied for grape protection throughout the entire world (Teixeira, et al., 2004 and Likas, et al., 2007). Such pesticides are registered and recommended in pest control program in Egypt which characterized by a low mammalian toxicity (Codex, 2006).

Extensive use of pesticides in modern agriculture to combat plant pests has received much attention because pesticide residues in food commodities may be hazardous to human health (Mansour, 2007). During the last two decades, considerable emphasis has been laid on increasing grapes production to enhance export capabilities (Mansour,2005). However, the development of the export market of fresh grape is hindered by concerns about pesticide residues and inadequate monitoring programs (EU, 2007).

The present investigation, aims to determine the residue levels of the tested pesticides, on grapes leaves and fruits when recommended dose is used. Also, the study aims to detect the pre-harvest intervals (PHI) for the mentioned pesticides to avoid health hazards and to facilitate the national and international trade.

\section{MATERIALS AND METHODS}

\section{Tested Pesticides:}

Azoxystrobin, IUPAC name (methyl (E)-2-\{2-[6(2- cyanophenoxy) pyrimidin- 4 -yloxy] phenyl $\}-3-$ methoxyacrylate) was used as suspension concentrate (Amistar 25\%SC) introduced by Zenca Agrochemicals.

Fenhexamid, ( $N$-(2, 3-dichloro-4-hy-droxyphenyl)1-methylcyclohexane- carboxamide) was provided as Telidor 50\% SC manufactured by Bayer.

Lufenuron, $(R S)$ - 1 - [2,5 - dicloro - 4- (1,1,2,3,3,3hexafluoropropoxy)phenyl]-3-(2,6-difluorobenzoyl) urea was formulated as emulsifiable concentrate as Match 5\% EC and purchased from Novartis.

Pesticide analytical standards, azoxystrobin, fenhexamid and lufenuron with purity of $95 \%$ were used for chromatographic standardization.

\section{Field application and sampling:}

The field experiments were carried out in plots (1/20 of Feddan for each plot) at Shanessa village, Dahkahlia Governorate, Egypt. Azoxystrobin (Amistar $25 \% \mathrm{SC}$ ), fenhexamid (Telidor 50\% SC) and lufenuron (Match 5\% EC) were sprayed on grapes in June $25^{\text {th }}$, 2008 , at the rates of 50,300 and $40 \mathrm{ml} / 100 \mathrm{~L}$ water respectively, using a knapsack sprayer fit with a single nozzle. One plot was left untreated as control check and for recovery purposes.

Samples of treated and untreated vine leaves and grape fruits were randomly collected in three replicates at different intervals i.e., one hour and then 1, 3, 6, 10, 15 and 21 days after pesticides application for residue

\footnotetext{
${ }^{1}$ Central Pesticide Lab. Agricultural Research Center, Alexandria

${ }^{2}$ Central Pesticide Lab. Agricultural Research Center, Giza

Received Febuary25, 2009, Accepted March15, 2009
} 
analysis. Each sample was chopped and divided into sub samples prepared for residue analysis.

\section{Methods of Analysis:}

\subsection{Extraction Procedures:}

\section{Extraction of Azoxystrobin and Fenhexamid}

The method of Mollhof, (1975) with minor modification was used as follow; one hundred grams of plant samples treated with azoxystrobin or fenhexamid were homogenized with $200 \mathrm{ml}$ distilled methanol in a Warning blender for $3 \mathrm{~min}$ at high speed and filtered through a dry cotton pad into a graduated cylinder. The methanol extract was partitioned with $3 \times 50 \mathrm{ml}$ methylene chloride and $30 \mathrm{ml}$ of saturated sodium chloride solution. The combined methylene chloride phases were filtered through anhydrous sodium sulfate and evaporated almost to dryness using a rotary evaporator at 40 ? $\mathrm{C}$.

\section{Extraction of Lufenuron}

Grapes treated with lufenuron were extracted according to Krause (1980). A representative sample of leaves or fruits (20 grams) was homogenized with $40 \mathrm{ml}$ acetone for $30 \mathrm{sec}$. Sixty milliliters dichloromethane petroleum ether 60-80 (1:1) were added to the mixture and rehomogenized for $1 \mathrm{~min}$. After centrifugation of homogenate for $5 \mathrm{~min}$. at $4000 \mathrm{rpm}$, the supernatant (organic phase) was decanted into graduated flask to measure the volume of extract. Twenty- five $\mathrm{ml}$ of the extract were concentrated to approximately dryness using a rotary evaporator.

\subsection{Clean up Procedures:}

\section{Clean up of Azoxystrobin}

The residue of azoxystrobin extract was dissolved in $5 \mathrm{ml}$ methanol and cleaned up according to the method of Johnson, (1963) with minor modification using coagulating solution $(0.5 \mathrm{gm}$ ammonium chloride and $1 \mathrm{ml} 85 \%$ orthophosphoric acid solution in $400 \mathrm{ml}$ distilled water). The extract was thoroughly mixed with $10 \mathrm{ml}$ of cooled freshly prepared coagulating solution and quantitatively transferred, and then filtered through a chromatographic columns of $2.5 \mathrm{~cm}$ diameter packed with a $5 \mathrm{~cm}$ layer of Hyflo-super cell. The column was eluted three times using a mixture of $5 \mathrm{ml}$ methanol and $10 \mathrm{ml}$ coagulating solution. The filtrates were then collected in $250 \mathrm{ml}$ separatory funnel and extracted with $3 \times 50 \mathrm{ml}$ methylene chloride. The final extract was concentrated to almost dryness using rotary evaporator and then dissolved in $2 \mathrm{ml}$ ethyl acetate for GLC analysis.

\section{Clean up of Fenhexamid}

The extract was evaporated and the residue was dissolved in $10 \mathrm{ml}$ of ethyl acetate and mixed with $0.5 \mathrm{~g}$ of activated charcoal, and then shaken for $2 \mathrm{~min}$. The mixture was filtered through filter paper (Whatman No.1) and the filtrate was rinsed with $25 \mathrm{ml}$ ethyl acetate (Al- Samariee et al., 1988). The filtrates were collected and concentrated almost to dryness using a rotary evaporator at 40?C; the volume was adjusted to $2 \mathrm{ml}$ for all samples and analyzed using HPLC.

\section{Clean up of Lufenuron}

The method of Krause (1980) was used for cleaning up of lufenuron extract. The extract residue was dissolved in $20 \mathrm{ml}$ dichloromethane and mixed with one gram of the adsorbing mixture (activated charcoal: Celite 545 at the ratio of 1:4 w/w), and then shaken for $2 \mathrm{~min}$. The mixture was filtered through anhydrous sodium sulfate on a cotton pad and then the precipitate was rinsed with $20 \mathrm{ml}$ dichloromethane. The final filtrate was concentrated using rotary evaporator under vacuum at $40{ }^{\circ} \mathrm{C}$.

\subsection{Chromatographic Analysis of Tested Pesticides:}

Analysis of Azoxystrobin

Quantitative analysis of azoxystrobin residues was performed using gas liquid chromatograph (GLC), HP 6890 serial equipped with electron capture detector (ECD) and capillary column HP-5 (30 m x $0.25 \mathrm{~mm}$ i.d $\mathrm{x} 0.25 \mu \mathrm{m}$ film thickness). The temperatures were $300^{\circ} \mathrm{C}$ and $260^{\circ} \mathrm{C}$ for detector and injector, respectively. The column temperature was programmed at $160^{\circ} \mathrm{C}$ for $2 \mathrm{~min}$., and raised to $260^{\circ} \mathrm{C}$ at the rate of $5^{\circ} \mathrm{C} / \mathrm{min}$., and then holed for $8 \mathrm{~min}$. The flow rate of nitrogen carrier gas was $3 \mathrm{ml} / \mathrm{min}$. The method showed linearity for all samples with a very high correlation coefficient $(r=$ 0.999). Under the optimized GLC - ECD conditions, the retention time of Azoxystrobin was $2.7 \mathrm{~min}$.

\section{Analysis of Fenhexamid and Lufenuron}

Fenhexamid and lufenuron residues were determined using high performance liquid chromatograph (HPLC). Agilent 1100 series equipped with photo diode array detector was set at 230 and 220 $\mathrm{nm}$ for fenhexamid and lufenuron, respectively. The analytical column Nucleosil - C18, 5 um (4 x $250 \mathrm{~mm}$ ) was used. The mobile phase was acetonitrile - water $70: 30$ at flow rate of 0.5 and $1 \mathrm{ml} / \mathrm{min}$.for fenhexamid and lufenuron, respectively. Under these conditions, the absolute retention times were 5.3 and $1.6 \mathrm{~min}$. for fenhexamid and lufenuron, respectively.

Percentage recovery for each of tested pesticides, i.e., azoxystrobin, fenhexamid and lufenuron from grape leaves and fruits was assessed at fortification level of $0.1 \mathrm{ppm}$. The fortified samples were extracted, cleaned up and determined using chromatographic methods as previously mentioned. 


\section{RESULTS AND DISCUSSIONS}

Analysis of Tested Pesticides on Grape Leaves and Fruits:

To evaluate accuracy of analytical procedure, grape leaves and fruit samples were spiked with $(0.1 \mathrm{ppm})$ of the tested pesticides. Table (1) shows that the average recovery of azoxystrobin, fenhexamid and lufenuron were $89.9,82.15$ and $81.7 \%$ for leaves, respectively, and $90.22,88.64$ and $87.9 \%$ for fruits respectively. These values are supported with those obtained by Krause (1980), Al- Samariee et al., (1988) and Teixeira, et al., (2004). It was reported that average recovery was $87.6 \%$, for grape samples spiked with azoxystrobin (Bursić, et al., 2007), >81\% for grape samples fortified with fenhexamid (Likas, et al., 2007) and $98.23 \%$ for lufenuron extracted (Ahire, et al., 2008), using procedures which are almost similar to that in the present investigation.

Table 1. Recovery Percentages of Tested Pesticides from Leaves and Fruits of Grapes

\begin{tabular}{ccc}
\hline \multirow{2}{*}{ Pesticide } & \multicolumn{2}{c}{ Recovery (\%) } \\
\cline { 2 - 3 } & Leaves & Fruits \\
\hline Azoxystrobin & 89.90 & 90.22 \\
Fenhexamid & 82.15 & 88.64 \\
Lufenuron & 81.70 & 87.90 \\
\hline
\end{tabular}

Residue analysis of Azoxystrobin

Azoxystrobin, a systematic analog of the fungal metabolites of the strobilurins and oudemansins, has a very broad spectrum of activity and is effective against fungal pathogens belonging to the different groups (Schirra, et al., 2002). It inhibits mitochondrial respiration by blocking electron transfer between cytochrom $b$ and cytochrom $c_{1}$. It is not persistent in the environment, expected to be safe to nontarget species, and is used on a wide range of crops (Ishii, et al., 2001).
Residues of azoxystrobin in grape leaves and fruits after treatment $(50 \mathrm{ml} / 100 \mathrm{~L}$ water $)$, at the period of one hour, 1, 3, 6, 10, 15 and 21 days are depicted out in Table (2). The initial deposits of azoxystrobin were 4.85 ppm and $1.86 \mathrm{ppm}$ in leaves and fruits of treated grapes, respectively. The residues of azoxystrobin declined to $0.12 \mathrm{ppm}$ on fruit after 10 days of application, and it was undetectable after 21 days. Only $0.54 \%$ of the initial deposit was detected on fruit after 15 days (Fig.2). The residues on grape leaves declined to 0.59 ppm after 10 days to represent $12.17 \%$ of the initial deposit (Fig. 1). The half life values $\left(\mathrm{t}_{0.5}\right)$ of azoxystrobin were calculated to be 3.01 and 2.8 days for grape leaves and fruits, respectively. According to the maximum residue limit (MRL) value of azoxystrobin on grapes (2 ppm) (EU, 2007), the safe harvest interval (PHI) was suggested to be 6 days for grapes.

Residue analysis of Fenhexamid

Fenhexamid is one of the new generations of fungicides used for fungal disease control in different agricultural crops (Tomlin, 2000). It is a protective specific fungicide that belongs to the newly discovered chemical group of hydroxyanilides; inhibit germ tube elongation and mycelium growth (Likas, et al., 2007).

The data representing the residue levels and percent dissipation of fenhexamid on grape leaves and fruits were presented in Table (3). Such data indicate that the initial concentrations were 23.45 and $5.24 \mathrm{ppm}$ on leaves and fruit samples, respectively, one hour after fenhexamid (50\% SC) application at the rate of $300 \mathrm{ml} / 100 \mathrm{~L}$ water. The level of fenhexamid residues on grape leaves were $19.5,11.2,4.35,0.18$ and $0.02 \mathrm{ppm}$ after 1, 3, 6,10 and 15 days of application, respectively, while it was at 21 days under detectable limits. Whereas, the residue level on grape fruit samples decreased gradually to $0.02 \mathrm{ppm}$ after 10 days and it wasn't

Table 2. Azoxystrobin Residue levels in Grape Leaves and Fruits

\begin{tabular}{|c|c|c|c|c|}
\hline \multirow[b]{2}{*}{$\begin{array}{c}\text { Time after } \\
\text { applicatio } \\
n\end{array}$} & \multicolumn{2}{|l|}{ Leaves } & \multicolumn{2}{|l|}{ Fruits } \\
\hline & $\begin{array}{c}\text { Residue Concentration } \\
\mathrm{mg} / \mathrm{kg}( \pm \text { S.D })\end{array}$ & $\begin{array}{c}\text { Dissipation } \\
(\%)\end{array}$ & $\begin{array}{c}\text { Residue Concentration } \\
\text { mg/kg }( \pm \text { S.D })\end{array}$ & $\begin{array}{c}\text { Dissipation } \\
(\%)\end{array}$ \\
\hline 1 hour & $4.85( \pm 0.0058)$ & 0.00 & $1.86( \pm 0.0153)$ & 0.00 \\
\hline 1 day & $3.58( \pm 0.010)$ & 26.18 & $1.16( \pm 0.0115)$ & 37.64 \\
\hline 3 days & $2.57( \pm 0.0153)$ & 47.01 & $0.86( \pm 0.0153)$ & 53.76 \\
\hline 6 days & $0.86( \pm 0.010)$ & 82.27 & $0.38( \pm 0.0173)$ & 79.57 \\
\hline 10 days & $0.59( \pm 0.010)$ & 87.83 & $0.12( \pm 0.0115)$ & 93.55 \\
\hline 15 days & $0.03( \pm 0.010)$ & 99.38 & $0.01( \pm 0.0012)$ & 99.46 \\
\hline 21 days & $0.01( \pm 0.0006)$ & 99.79 & $* N D$ & 100 \\
\hline$* * \mathbf{t}_{0.5}$ & 3.01days & & 2.8 days & \\
\hline MRL & \multicolumn{4}{|c|}{$2 \mathrm{mg} / \mathrm{kg}$ (EU 2007) } \\
\hline PHI & \multicolumn{4}{|c|}{6 days } \\
\hline
\end{tabular}

*ND: Not detectable

**The half-life value $\left(\mathrm{t}_{0.5}\right)$ was calculated using following equation: 
$\mathrm{t}_{0.5}=\ln 2 / \mathrm{K}=0.693 / \mathrm{K}(\mathrm{K}$ is reaction constant rate $)$

Table 3. Fenhexamid Residue levels in Grape Leaves and Fruits

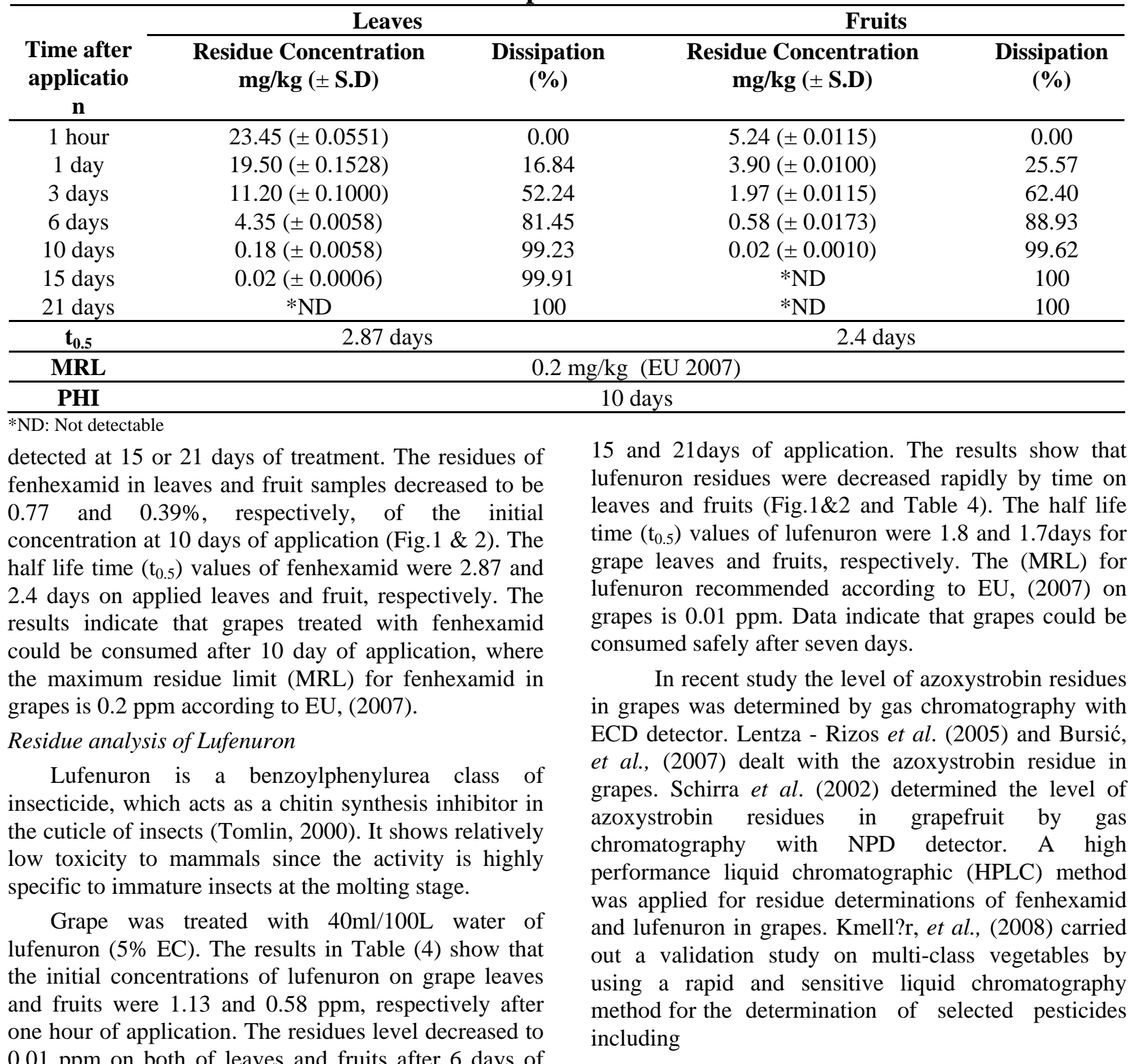
$0.01 \mathrm{ppm}$ on both of leaves and fruits after 6 days of treatment. Lufenuron wasn't detected in samples after

Table 4. Lufenuron Residue levels in Grape Leaves and Fruits

\begin{tabular}{ccccc}
\hline \multirow{2}{*}{\begin{tabular}{c} 
Time after \\
applicatio \\
\cline { 3 - 5 }
\end{tabular}} & $\begin{array}{c}\text { Residue Concentration } \\
\mathbf{m g} / \mathbf{k g}( \pm \mathbf{S . D})\end{array}$ & $\begin{array}{c}\text { Dissipation } \\
(\boldsymbol{\%})\end{array}$ & $\begin{array}{c}\text { Residue Concentration } \\
\mathbf{m g} / \mathbf{k g}( \pm \mathbf{S . D})\end{array}$ & $\begin{array}{c}\text { Dissipation } \\
(\boldsymbol{\%})\end{array}$ \\
\hline 1 hour & $1.13( \pm 0.0153)$ & 0.00 & $0.58( \pm 0.0173)$ & 0.00 \\
1 day & $0.96( \pm 0.0321)$ & 15.04 & $0.51( \pm 0.0058)$ & 12.07 \\
3 days & $0.18( \pm 0.0153)$ & 84.07 & $0.08( \pm 0.0115)$ & 86.21 \\
6 days & $0.01( \pm 0.0010)$ & 99.11 & $0.01( \pm 0.0010)$ & 98.27 \\
10 days & $0.008( \pm 0.0012)$ & 99.29 & $* N D$ & 100 \\
15 days & $* N D$ & 100 & $* N D$ & 100 \\
21 days & $* N D$ & 100 & $* N D$ & 100 \\
\hline
\end{tabular}




\begin{tabular}{|c|c|c|}
\hline$t_{0.5}$ & 1.8 days & 1.7 days \\
\hline MRL & \multirow{2}{*}{\multicolumn{2}{|c|}{$\frac{0.01 \mathrm{mg} / \mathrm{kg} \text { (EU 2007) }}{7 \text { days }}$}} \\
\hline PHI & & \\
\hline
\end{tabular}

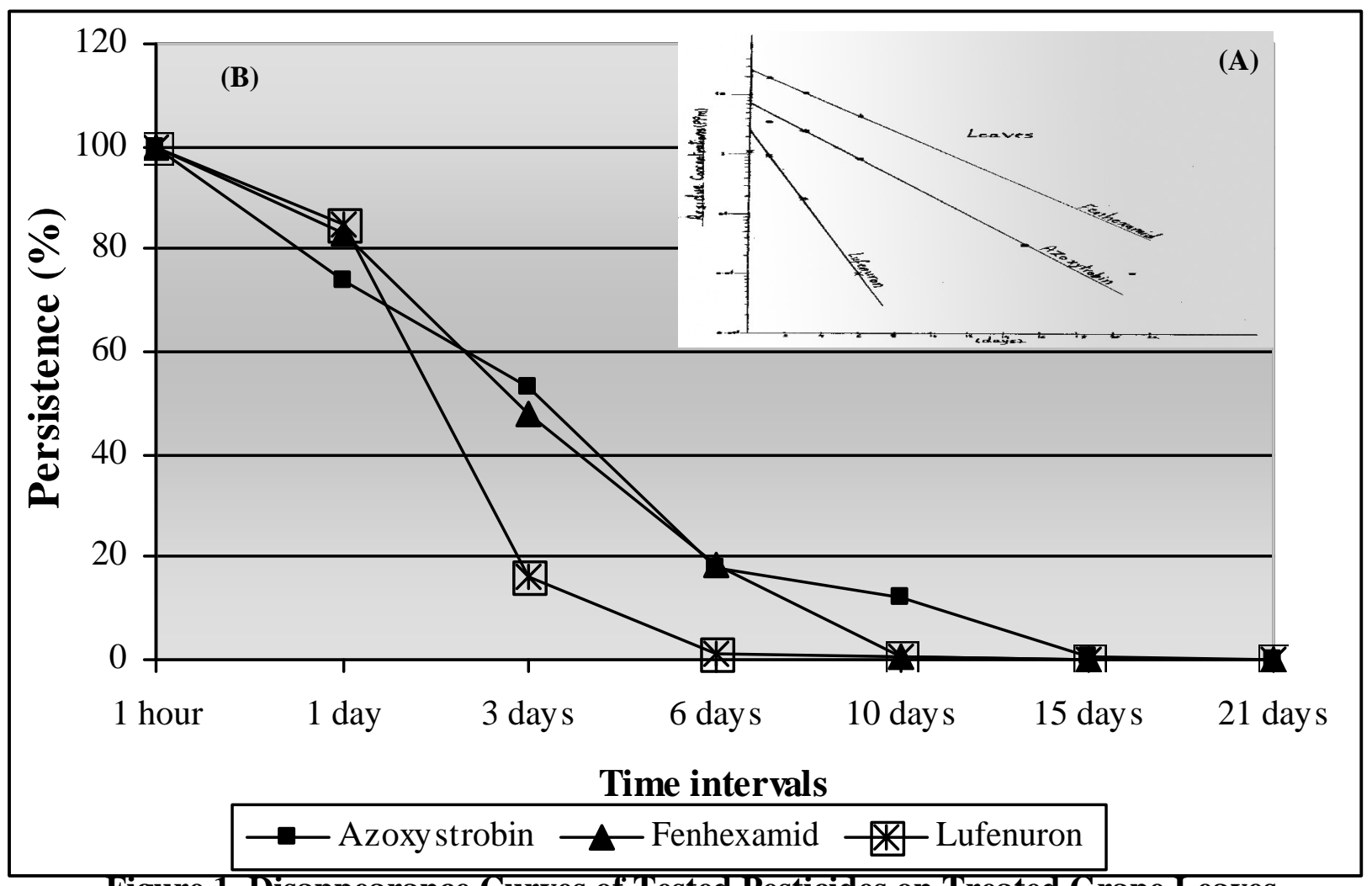

Figure 1. Disappearance Curves of Tested Pesticides on Treated Grape Leaves

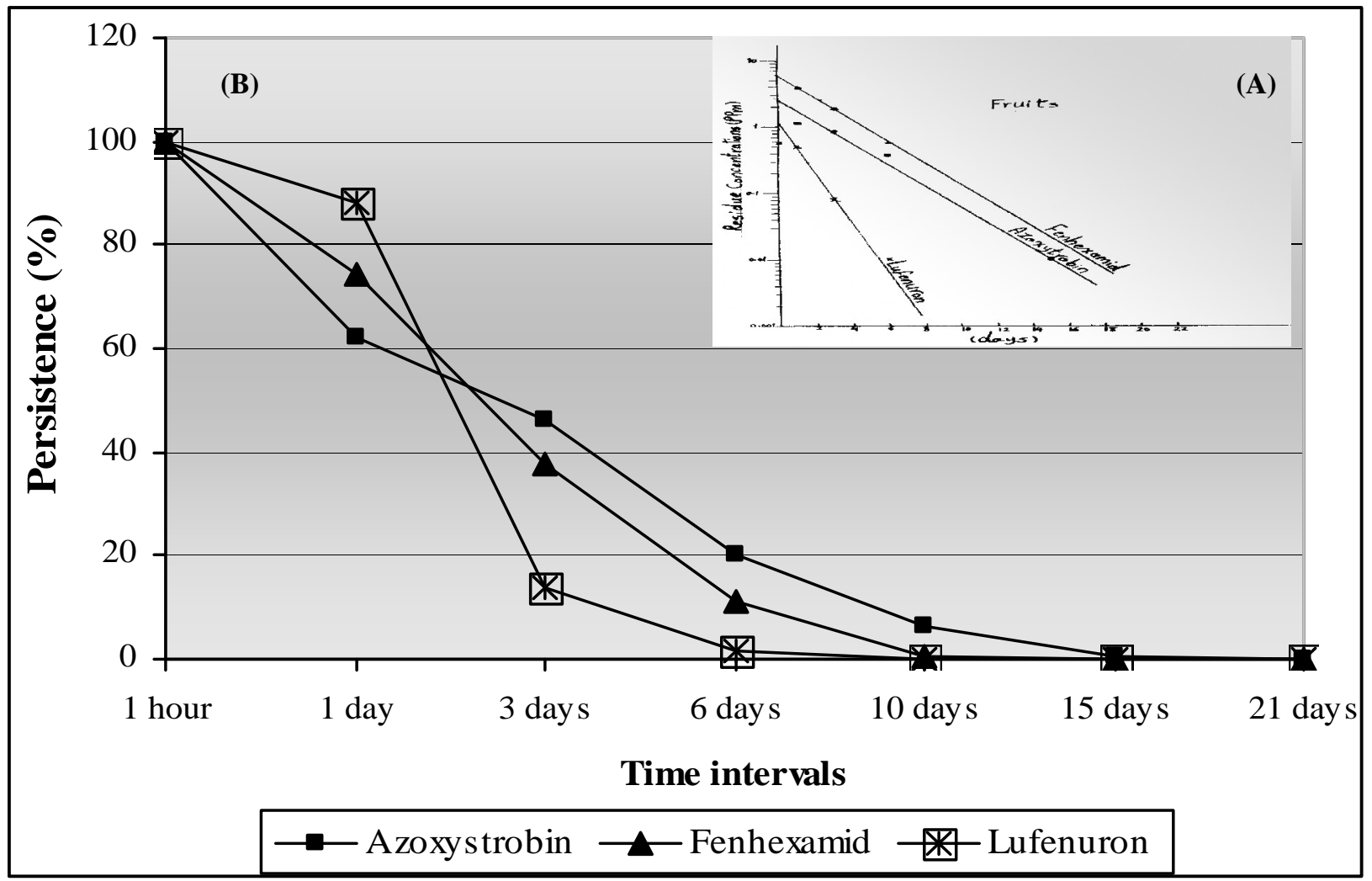




\section{Figure 2. Disappearance Curves of Tested Pesticides on Treated Grape Fruits}

fenhexamid and lufenuron. Also, Liquid chromatography methods were reported for determining fenhexamid residues in whole grape and grape skin (Teixeira, et al., 2004), as well as lufenuron residues in vegetables (Khay, et al., 2008).

The present results indicate that the residues of azoxystrobin declined on grape fruits to $0.12 \mathrm{ppm}$, while the residues on leaves were found to be $0.59 \mathrm{ppm}$ after 10 days of application. These results were supported by Chen, et al., (2004) who found 0.15 ppm of the initial azoxystrobin residues on wax apple at 12 days after application. Also, they cited that residues were found to persist for a longer time, e.g., 18 days on cabbage, and 9 days on leafy vegetables, after treatment.

The present investigation reveals that, dissipation of fenhexamid on grape leaves and fruits decreased to $<0.02 \mathrm{ppm}$ after 15 days, and it wasn't detectable at 21 days of treatment. By comparing these values, it can be seem that concentrations of fenhexamid residues considerably decreased on vine fruits compared with leaves, these finding was also observed by other investigators (Teixeira, et al., 2004). Also, Sannino, et al., (2004) found that none of grape fruit samples contained fenhexamid residues higher than $0.01 \mathrm{ppm}$ after 21 days of application.

The present study also indicates that the residue of lufenuron on grapes was decreased through 21 days of application. These results are in agreement with those found by other authors during the study of the lufenuron behaviour and determination of its residues in peppers and zucchinis grown in greenhouses by HPLC through 21 days of application with recommended rate (Lo'pezLo'pez, et al., 2003).

Based on the dissipation pattern of tested pesticide residues in relation to their respective prescribed maximum residue limits, PHI values are 6, 10 and 7 days suggested for grapes treated with azoxystrobin, fenhexamid and lufenuron, respectively. These data are in agreement with those obtained by Bursić, et al., (2007) who cited that the residues of azoxystrobin in cucumber samples collected 7 days after treatment were below the MRL. Also, Likas, et al., (2007) showed that the levels of fenhexamid residues in grape samples after 10 days were clearly below the EU established MRL values, thus causing no problems in terms of food safety. In order to guarantee safe consumption of vegetables, Lo'pez-Lo'pez, et al., (2003) have estimated suitable pre-harvest intervals complying with the maximum residue levels of lufenuron established by the Spanish Government. In all cases, such pre-harvest intervals were shorter than those specified by the manufacturers of commercial formulates.

\section{REFERENCES}

Ahire, K. C.; Arora, M. S. and Mukherjee, S. N. (2008). Development and application of a method for analysis of lufenuron in wheat flour by gas chromatography-mass spectrometry and confirmation of bio-efficacy against Tribolium castaneum (Herbst) (Coleoptera: Tenebrionidae). J. Chromatography B, 861:16-21.

Al-Samariee, A. I.; Shaker, K. A. M. and Al- Bassny, M. A. (1988). Residue levels of three organophosphorus insecticides in sweet pepper grown in commercial green houses. Pestic. Sci. 22: 189- 194.

Bursić, V.; Lazić, S.; Stojšin, V.; Bagi, F. and Balaž, F. (2007). Determination of azoxystrobin residues in cucumbers. Zbornik predavanj in referatov 8 . slovenskega posvetovanja o varstvu rastlin 257: 6 - 7 .

Chen, M. F.; Chien, H. P.; Wong, S. S. and Li, G. C. (2004). Dissipation of the fungicide azoxystrobin in Brassica vegetables. Plant Prot. Bull. 46: 123 - 130.

Codex, (2006). Comments on the proposed draft revision of the list of methods for pesticide residue analysis including methods of determination for dithiocarbamates at step 3. Codex Committee on Pesticide Residues.

EU, (2007). Regulation of export of fresh grapes to the European Union through control of pesticide residues for the 2008 grape season. Agricultural and Processed Food Products Export Development Authority. QMC/GEN/049/2007.

Horticulture Research Institute (HRI), 2008. Viticulture research department statistics. Horticulture Research Institute, Agriculture Research Center, Ministry of Agriculture. Newsletter, 2008. www.hortinst.com.

Ishii, H.; Fraaije, B. A.; Sugiyama, T.; Noguchi, K.; Nishimura, K.; Takeda, T.; Amano, T., and Hollomon, D.W. (2001). Occurrence and molecular characterization of strobilurin resistance in cucumber powdery mildew and downy mildew. Phytopathol. 91: 1166-1171.

Johnson, D.P. (1963). Determination of seven insecticide residues in fruit and vegetables. J.A.O.A.C., 46: $234-$ 237.

Khay, S.; Choi, J. H.; Abd El-Aty, A. M.; Mamun, M. I. R.; Park, B. J.; Goudah, A.; Shin, H. C. and Shim, J. H. (2008). Dissipation behavior of lufenuron, benzoylphenylurea insecticide, in/on Chinese cabbage applied by foliar spraying under greenhouse conditions. Bull. Environ. Contamin. Toxicol. 81(4):369-372. 
Kmell?r, B.; Fodor, P.; Pareja, L.; Ferrer, C.; Marthez-Uroz, M. A.; Valverde, A. and Fernandez-Alba, A. R. (2008). Validation and uncertainty study of a comprehensive list of 160 pesticide residues in multi-class vegetables by liquid chromatography-tandem mass spectrometry. $J$. Chromatogr. A. 1215 (1-2): 37-50.

Krause, R.T. (1980). Multiresidue method for determining $\mathrm{N}$-methyl carbamate insecticides in crops, using high performance liquid chromatograph J.A.O.A.C., 63: 1114 - 1124 .

Lentza-Rizos, C.; Avramides, E. J. and Kokkinaki, K. (2005) Residues of azoxystrobin from grapes to raisins. 4 MGPR International Symposium of pesticides in food and the environment in Mediterranean countries and MGPR annual meeting. 2005, 72.

Likas, D.T.; Tsiropoulos, N.G. and Miliadis, G.E. (2007). Rapid gas chromatographic method for the determination of famoxadone, trifloxystrobin and fenhexamid residues in tomato, grape and wine samples. J. Chromatography A. 1150: 208-214.

Lo' pez-Lo' pez, T.; Mart'inez-Vidal, J. L.; Gil-Garc'ia, M. D.; Mart'inez-Galera, M. and Rodr'iguez-Lallena, J. A. (2003). Benzoylphenylurea residues in peppers and zucchinis grown in greenhouses: determination of decline times and pre-harvest intervals by modeling. Pest Manag Sci. 60:183-190.
Mansour, K. (2005). The status of production and handling grapes in the region Egypt, Sudan, Somali, Yemmen. Ain Shams Univ., Fac. Agric. Report. Www.egfar.org.

Mansour, S.A. (2007). Environmental impact of pesticide in Egypt. Reviews of environmental contamination and toxicology. 196.

Mollhoff, E. (1975). Method for gas chromatographic determination of residues of tokuthion and its oxon in plant samples. Pflanzenshutz-Nachrichton, Bayer. 28:882-887.

Sannino, A.; Bolzoni, L. and Bandini, M. (2004). Application of liquid chromatography with electrospray tandem mass spectrometry to the determination of a new generation of pesticides in processed fruits and vegetables. $J$. Chromatogr. A. 1036(2):161-169.

Schirra, M.; Cabras, P.; Angioni, A. and Brandolini, V. (2002). Residue levels and storage decay control in cv. Star ruby grapefruit after dip treatments with azoxystrobin. J. Agric. Food Chem., 50: 1461-1464.

Teixeira, M. J.; Aguiar, A.; Afonso, C. M. M.; Alves, A. and Bastos, M. S. M. (2004). Comparison of pesticides levels in grape skin and in the whole grape by a new liquid chromatographic multiresidue methodology. Analytica. Chimica. Acta. 513: 333-340.

Tomlin, C.D.S. (2000). The Pesticide Manual, $12^{\text {th }}$ ed., British Crop Protection Council, Suffolk, U.K. 


\section{الملتخص العربي}

\section{التقدير الكروماتوجر افي لمتبقيات الأزوكسيتروبين، الفنهكساميد والليوفنيورون في العنب}

$$
\text { منال منتصر، هند معمود }
$$

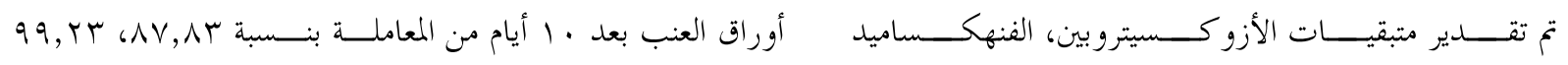

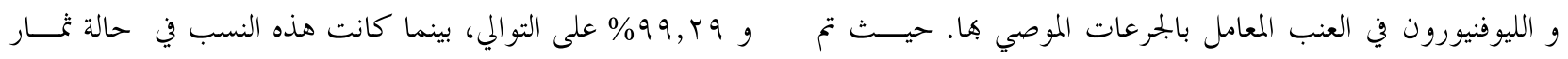

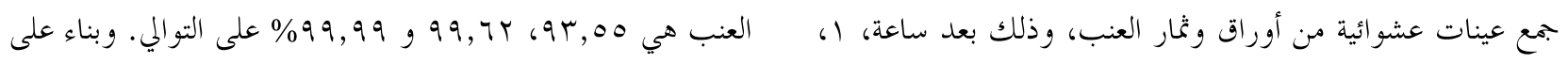

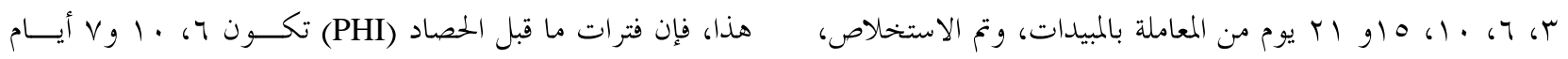

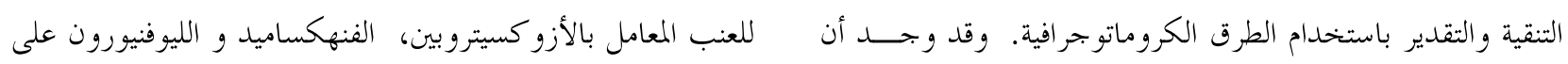

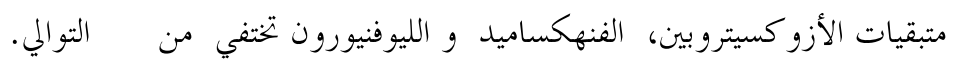

